\title{
PENGARUH PARTISIPASI PENYUSUNAN ANGGARAN PADA KINERJA APARAT PEMERINTAH DAERAH DENGAN BUDAYA ORGANISASI, MOTIVASI, DAN GAYA KEPEMIMPINAN SEBAGAI VARIABEL MODERATING
}

\author{
Lalu Yoga Putra Wiguna ${ }^{1}$ \\ I Made Sukartha ${ }^{2}$ \\ Ida Bagus Putra Astika ${ }^{3}$ \\ $\mathbf{1 , 2 , 3}$ Fakultas Ekonomi dan Bisnis, Universitas Udayana (Unud), Bali, Indonesia
e-mail: laluyogaputrawiguna@gmail.com
}

\begin{abstract}
ABSTRAK
Penelitian ini bertujuan menguji pengaruh partisipasi penyusunan anggaran pada kinerja dengan faktor-faktor kondisional (budaya organisasi, motivasi, dan gaya kepemimpinan). Kinerja yang diuji adalah kinerja Aparat Pemerintah Daerah Kabupaten Lombok Utara. Secara spesifik penelitian ini menguji, pengaruh partisipasi penyusunan anggaran pada kinerja, serta pengaruh partisipasi penyusunan anggaran pada kinerja dengan budaya organisasi, motivasi, dan gaya kepemimpinan sebagai variabel moderasi. Penelitian dilakukan dengan metode survei dengan menyebarkan kuesioner kepada para pejabat yang terlibat langsung dalam proses penyusunan anggaran, yaitu tiga orang pejabat di tiap-tiap Satuan Kerja Perangkat Daerah (SKPD). Kuesioner yang dapat digunakan berjumlah 93 kuesioner. Analisis data dilakukan dengan menggunakan analisis regresi moderasi interaksi (MRA). Hasil penelitian menunjukkan (1) partisipasi penyusunan anggaran berpengaruh positif pada kinerja aparat pemerintah; (2) budaya organisasi, motivasi, dan gaya kepemimpinan memperkuat pengaruh positif partisipasi penyusunan anggaran pada kinerja aparat pemerintah.

Kata Kunci: Kinerja Aparat Pemerintah Daerah, Partisipasi Penyusunan Anggaran;

Budaya Organisasi, Motivasi, Gaya Kepemimpinan.
\end{abstract}

\begin{abstract}
This study aims to examine the effect of budget participation on the performance of conditional factors (organizational culture, motivation, and leadership style). Performance tested was the performance of government officials in North Lombok regency. Specifically, this research examines the influence of budget participation on the performance, as well as the effect of budget participation on the performance of the organizational culture, motivation, and leadership style as a moderating variable. The research was conducted by survey by distributing questionnaires to officials directly involved in the budgeting process, the three officials in each of the regional work units (SKPD). The questionnaire can be used amounted to 93 questionnaire. Data analysis was performed using Moderated Regression Analysis (MRA) The results showed (1) budget participation has positive influence on the performance of government officials; (2) moderate the influence of organizational culture, motivation, and The leadership style moderating influence of budget participation with the performance of government officials.
\end{abstract}

Keyword: the performance of government officials, budget participation, organizational culture, motivation, and The leadership style 


\section{PENDAHULUAN}

Pemerintah daerah dituntut untuk memberikan pelayanan kepada masyarakat dengan menerapkan asas pelayanan publik seperti transparan, akuntabilitas, pastisipatif, kesamaan hak, keseimbangan hak, serta kewajiban. Untuk melaksanakan hak dan kewajibannya serta melaksanakan tugas yang dibebankan oleh rakyat, pemerintah harus mempunyai suatu rencana yang matang untuk mencapai hasil yang maksimal.

Rencana-rencana tersebut disusun secara baik dan selanjutnya dipakai sebagai pedoman dalam setiap langkah pelaksanaan tugas Negara. Rencana pemerintah untuk melaksanakan keuangan Negara atau Daerah dibuat perencanaan yang dituangkan dalam bentuk anggaran. Didalam anggaran akan dapat dilihat seberapa besar fungsi pemerintah dalam melaksanakan berbagai urusan pemerintahan yang menjadi tanggungjawabnya dan faktor-faktor apa saja yang dapat mempengaruhinya. Dalam anggaran akan terlihat seberapa besar fungsi dari pemerintahan dalam melaksanakan fungsi pemerintahannya.

Keberhasilan dalam proses penyusunan anggaran salah satunya dapat dipengaruhi oleh sikap dan prilaku pihak yang terlibat dalam proses penyusunan anggaran. Proses penganggaran menggunakan kinerja yang diatur dalam Permendagri Nomor 59 Tahun 2007 tentang pedoman dalam pembentukan rancangan anggaran pendapatan dan belanja daerah (RAPBD) yang dilaksanakan oleh tim anggaran eksekutif bersama-sama unit organisasi perangkat daerah (unit kerja). Hasil 
rancangan anggaran akan tercantum pada suatu dokumen rencana kegiatan anggaran satuan kerja perangkat daerah. Didalam dokumen rencana kegiatan anggaran satuan kerja perangkat daerah berisi tentang standar analisis belanja, tolak ukur kinerja dan standar biaya sebagai instrument pokok dalam anggaran kinerja.

Secara umum, kinerja merupakan prestasi yang dicapai oleh organisasi dalam periode tertentu. Ukuran kinerja suatu organisasi sangat penting, guna evaluasi dan perencanaan masa depan. Pada organisasi sektor publik, anggaran dapat digunakan untuk menilai kinerja para pimpinan Satuan Kerja Perangkat Daerah (SKPD), sehingga anggaran mampu mempengaruhi perilaku dan kinerja aparat pemerintah daerah. proses penyusunan anggaran merupakan kegiatan yang penting dan kompleks, adanya kemungkinan akan menimbulkan dampak fungsional dan disfungsional terhadap sikap dan perilaku anggota organisasi (Dedi, 2007).

Untuk mencegah dampak disfungsional anggaran tersebut, kontribusi terbesar dari kegiatan penganggaran terjadi jika semua pihak diperbolehkan untuk berpartisipasi dalam penyusunan anggaran. Para bawahan yang merasa aspirasinya dihargai dan mempunyai pengaruh pada anggaran yang disusun akan lebih mempunyai tanggungjawab dan konsekuensi moral untuk meningkatkan kinerja sesuai yang ditargetkan dalam anggaran.

Dengan partisipasi, akan terjadi mekanisme pertukaran informasi yang membuat manajer akan memperoleh informasi yang relevan dengan kerjasama. Informasi tersebut memungkinkan pemahaman yang lebih baik tentang tugas yang 
akan dilakukan, sehingga diharapkan kinerja aparat pemerintah akan meningkat. Penelitian empiris tentang partisipasi penyusunan anggaran terhadap kinerja aparat pemerintah telah banyak dilakukan oleh Wulandari (2013), Prihandini (2011), Septi (2010), Bangun (2009), Jalaluddin dan Bahri (2009), Nor (2007), Sumarno (2005), Indriantoro (1995), Fruscot dan Shearon (1991), Brownell dan Mccinnes (1986), Brownell (1982), dan Kenis (1979), yang menemukan bahwa terdapat hubungan positif dan signifikan antara partisipasi dalam penyusunan anggaran dan kinerja aparatur pemerintah.

Sedangkan hasil penelitian yang berbeda didapatkan oleh Nugrahani (2009), Anggraeni (2009), Brownell dan Hirst (1986), Milani (1975), Kenis (1975), Cherrington dan Cherrington (1973) Morse dan Reimer (1956), dan Studi mereka menyimpulkan bahwa partisipasi penganggaran mempunyai pengaruh yang tidak signifikan terhadap kinerja manajerial. Hasil yang sama juga diperoleh peneliti lain, seperti Bryan dan Locke (1967) dan Sterdry (1960) menunjukkan bahwa ada pengaruh negatif anatara partisipasi penganggaran terhadap kinerja manajerial.

Hal ini terjadi karena hubungan partisipasi penyusunan anggaran dengan kinerja aparat pemerintah daerah tergantung pada faktor-faktor yang situasional atau variabel kontijensi (Contigency Variable). Berdasarkan hasil penelitan yang tidak konsisten diatas, penulis tertarik untuk melakukan penelitian dengan judul Pengaruh Partisipasi Penyusunan Anggaran Pada Kinerja Aparat Pemerintah Daerah Dengan 
Budaya Organisasi, Motivasi dan Gaya Kepemimpinan Sebagai Variabel Moderasi Studi Empiris Pada SKPD Pemerintah Daerah Kabupaten Lombok Utara.

Alasan penulis memilih Kabupaten Lombok Utara sebagai obyek penelitian adalah karena berdasarkan sumber www.lombokpost.net ada beberapa rapor SKPD Pemerintah Daerah Kabupaten Lombok Utara tahun 2015 yang mengalami penurunan realisasi fisik dan keuangan sebesar 3\%. Ada 2 SKPD dari 31 SKPD yaitu, dinas kesehatan dan dinas pariwisata yang tidak melakukan eksekusi anggaran sehingga menyebabkan capaian realisasi rendah. Adapun permasalahan yang akan dirumuskan dalam penelitian ini adalah sebagai berikut: (1) Apakah partisipasi penyusunan anggaran berpengaruh pada kinerja aparat pemerintah daerah Kabupaten Lombok Utara? (2) Apakah budaya organisasi memoderasi pengaruh partisipasi penyusunan anggaran pada kinerja aparat pemerintah daerah Kabupaten Lombok Utara? (3) Apakah motivasi memoderasi pengaruh partisipasi penyusunan anggaran pada kinerja aparat pemerintah daerah Kabupaten Lombok Utara? (4) Apakah gaya kepemimpinan memoderasi pengaruh partisipasi penyusunan anggaran pada kinerja aparat pemerintah daerah Kabupaten Lombok Utara?

Penelitian ini menggunakan teori penetapan tujuan (goal setting theory). Teori penetapan tujuan atau goal-setting theory awalnya dikemukakan oleh Locke (1968), yang menunjukkan adanya keterkaitan antara tujuan dan kinerja seseorang terhadap tugas. Teori ini menjelaskan bahwa perilaku seseorang ditentukan oleh dua buah cognition yaitu values (nilai) dan intentions (tujuan). Orang telah menentukan 
goal atas perilakunya di masa depan dan goal tersebut akan mempengaruhi perilaku yang sesungguhnya terjadi. Perilakunya akan diatur oleh ide (pemikiran) dan niatnya sehingga akan mempengaruhi tindakan dan konsekuensi kinerjanya. Salah satu bentuk nyata dari penerapan goal-setting ini adalah anggaran. Sebuah anggaran tidak hanya mengandung rencana dan jumlah nominal yang dibutuhkan untuk melakukan kegiatan, tetapi juga mengandung sasaran yang spesifik yang ingin dicapai organisasi. Teori lainnya yang digunakan dalam penelitian ini yaitu, teori kontijensi. Menurut Otley (1980) teori kontijensi ini dapat digunakan untuk menganalisis desain dan sistem akuntansi manajemen untuk memberikan informasi yang dapat digunakan perusahaan untuk berbagai macam tujuan. Sedangkan menurut Wulandari (2011), mengatakan untuk merekonsiliasi temuan penelitian yang saling bertentangan, diperlukan pendekatan kontinjensi dengan mengevaluasi faktor-faktor kondisional, dalam penelitian ini misalnya kemungkinan adanya hal-hal yang dapat menyebabkan kinerja aparat menjadi lebih efektif. Pada partisipasi penyusunan anggaran, penggunaan teori kontijensi ini telah lama menjadi perhatian para peneliti. Para peneliti terdahulu menggunakan teori kontinjensi untuk menghubungkan pengaruh partisipasi anggaran terhadap kinerja pegawai. Pengaruh partisipasi penyusunan anggaran terhadap kinerja aparat pemerintah daerah mempunyai faktor-faktor kontijensi, faktor-faktor tersebut yang akan dibahas adalah faktor budaya organisasi motivasi dan gaya kepemimpinan. Faktor budaya organisasi, motivasi dan gaya kepemimpinan adalah variabel moderating, yang dapat memperkuat atau 
memperlemah pengaruh partisipasi penyusunan anggaran terhadap kinerja aparat pemerintah daerah.

Partisipasi dalam penyusunan anggaran merupakan kegiatan yang penting dalam sebuah organisasi. Tujuan organisasi akan mudah tercapai apabila anggotaanggota organisasi dilibatkan dalam menentukan langkah-langkah untuk mencapai tujuan dimaksud. Oleh karena itu bawahan perlu diberikan kesempatan untuk berpartisipasi dalam proses penyusunan anggaran organisasi.

Partisipasi dalam penyusunan anggaran merupakan proses dimana organisasi dan individu yang kinerjanya dievaluasi dalam memperoleh penghargaan berdasarkan pencapaian target anggaran, terlibat dan memiliki pengaruh dalam penyusunan target anggaran Brownnell (1982). Menurut Brownel (1982) partisipasi adalah suatu perilaku dan aktifitas yang dilakukan oleh aparat pemerintah selama aktivitas penyusunan anggaran berlangsung.

Siegel dan Marconi (1989) menyatakan bahwa partisipasi manajer dalam penyusunan anggaran dapat mengembangkan inisiatif sehingga para partisipan dapat menuangkan ide dan informasi, meningkatkan kebersamaan dan merasa memiliki, sehingga menjalin kerjasama di antara anggota dalam mencapai tujuan meningkat. Partisipasi atasan serta bawahan dalam proses penyusunan anggaran diperlukan untuk menyelaraskan tujuan setiap capaian dalam organisasi sebagai pusat pertanggungjawaban dengan tujuan organisasi antara keseluruhan. Pengukuran kinerja sektor publik adalah suatu sistem yang bertujuan untuk membantu manajer 
publik dalam menilai pencapaian suatu strategi melalui alat ukur finansial dan non finansial. Sistem pengukuran kinerja dapat dijadiakan sebagai pengendalian organisasi karena pengukuran kinerja diperkuat dengan menetapkan reward and punishment system (Sardjito dan Muthaher, 2007).

Adapun yang dimaksud dengan kinerja aparat adalah kinerja dari individu aparatur pemerintah dalam kegiatan pemerintahan yang meliputi perencanaan, investigasi, koordinasi, evaluasi, pengawasan, pemilihan staf, negosiasi dan perwakilan atau presentasi. Salah satu hal yang berkaitan erat dengan kinerja adalah partisipasi atasan dipemerintahan dalam proses penyusunan anggaran (Mahoney, 1963).

Hubungan antara partisipasi dalam proses penyusunan anggaran dan kinerja aparat merupakan salah satu topik yang sangat menarik perhatian para peneliti disebabkan dua alasan pokok sebagiamana yang telah dikemukakan oleh Brownell (1982) bahwa pada umumnya partisipasi dinilai sebagai suatu pendekatan atasan yang dapat meningkatkan kinerja organisasi. Hasil penelitian-penelitian yang dilakukan untuk menguji hubungan antara kedua variabel tersebut memberikan hasil yang tidak konsisten antara satu peneliti dengan peneliti yang lain.

Budaya organisasi adalah faktor yang paling kritis dalam organisasi. Efektivitas organisasi dapat ditingkatkan dengan menciptakan budaya yang kuat yang dapat digunakan untuk mencapai tujuan organisasi. Organisasi yang memiliki budaya kuat akan memiliki suatu ciri khas tertentu sehingga dapat memberikan daya tarik 
bagi individu untuk bergabung. Menurut Mondy and Noe III (1993:321) terdapat tiga faktor yang membentuk budaya dalam organisasi, yaitu: (1) komunikasi, (2) motivasi dan (3) kepemimpinan. Komunikasi merupakan transfer informasi, ide pemahaman dan perasaan diantara para anggota organisasi. Manajer yang ingin berhasil dalam organisasi harus mampu berkomunikasi secara efektif. Motivasi merupakan kemauan untuk berusaha dalam mengejar tujuan organisasi sebelumnya manajer tidak dapat secara langsung memotivasi bawahan karena memotivasi adalah masalah internal masing-masing individu. Tugas manajemen adalah menghadirkan budaya organisasi yang mendorong perilaku positif dari bawahannya, manajemen organisasi perlu memahami faktor-faktor yang memicu perilaku bawahan dan mengembangkan serta mempertahankan lingkungan yang produktif dalam organisasi, kepemimpinan merupakan proses mempengaruhi anggota organisasi untuk bertindak sesuai dengan keyakinan pemimpin.

Motivasi merupakan dorongan dimana seorang individu ingin dan berusaha untuk melaksanakan suatu tugas atau pekerjaan yang baik dan kesediaan untuk mengeluarkan tingkat upaya yang tinggi ke arah tujuan organisasi, yang dikondisikan oleh kemampuan upaya itu untuk memunuhi suatu kebutuhan individual (Robbins, 1986). Proses timbulnya motivasi seseorang merupakan gabungan dari konsep kebutuhan, dorongan, tujuan dan imbalan (Gitosudarmo dan Sudita, 1997).

Motivasi merupakan faktor-faktor yang ada dalam diri seseorang dalam mengarahkan perilakunya untuk memenuhi tujuan tertentu. Dalam konteks pekerjaan, 
motivasi adalah salah satu faktor penting dalam mendorong seorang karyawan untuk bekerja dengan mengeluarkan upaya yang tinggi untuk mencapai tujuan organisasi. Dikaitkan dengan anggaran maka dalam proses partisipasi penyusunan anggaran mungkin akan lebih efektif dalam kondisi karyawan mempunyai motivasi yang tinggi begitu pula sebaliknya (Mia, 1988). Robbins (1996) mengemukakan tentang keterlibatan karyawan yang dikatakan sebagai suatu proses partisipasi. Logika yang mendasari adalah dengan melibatkan para pekerja dalam keputusan-keputusan mengenai mereka dan dengan meningkatkan otonomi dan kendali mereka mengenai kehidupan kerja mereka, para karyawan akan menjadi lebih termotivasi, lebih berkomitmen terhadap organisasi, lebih produktif dan lebih terpuaskan dengan pekerjaan mereka.

Gaya kepemimpinan mengambarkan kombinasi yang konsisten dari falsafah, keterampilan, sifat dan sikap yang sering diterapkan seorang pemimpin ketika mencoba mempengaruhi kinerja bawahannya,. Gaya kepemimpinan merupakan dasar dalam mengklasifikasikan tipe kepemimpinan. Ada 2 kategori gaya kepemimpinan yang ekstrem, yaitu gaya kepemimpinan yang berorientasi tugas dan gaya kepemimpinan berorientasi hubungan.

Gaya kepemimpinan yang berorientasi tugas adalah suatu perilaku seorang pemimpin untuk mengatur dan merumuskan peranan-peranan dari anggota kelompok atau para pengikut, menerangkan kegiatan yang harus dikerjakan oleh masing-masing anggota, kapan dilakukan, dimana melaksanakannya dan bagaimana tugas-tugas itu 
harus dicapai. Sedangkan gaya kepemimpinan yang berorientasi hubungan adalah suatu perilaku seorang pemimpin yang ingin memelihara hubungan-hubungan antar pribadi diantara dirinya dengan anggota kelompok atau para pengikut dengan cara membuka lebar-lebar jalur komunikasi, mendelegasikan tanggungjawab dan memberikan kesempatan pada para bawahannya untuk menggunakan potensinya (Thoha, 2004).

Gaya kepemimpinan yang tepat adalah yang diarahkan kepada keterbukaan dan lebih bersifat humanis oleh Coster dan Fertakis (1968) disebut dengan consideration. Menurut Warrick (1981) gaya kepemimpinan memiliki beberapa tipe manajemen yang berbeda-beda. Indikator dari gaya kepemimpinan yaitu memperhatikan kebutuhan bawahan, simpati terhadap bawahan, menciptakan suasana saling percaya, memiliki sikap bersahabat dan menumbuhkan peran serta bawahan dalam pembuatan keputusan (Astuti, 2008).

Ogbonna dan Harris (2000) dalam penelitiannya menunjukkan bahwa kepemimpinan yang diperankan dengan baik oleh seorang pemimpin mampu memotivasi karyawan untuk bekerja lebih baik, hal ini akan membuat karyawan lebih hati-hati berusaha mencapai target yang diharapkan perusahaan hal tersebut berdampak pada kinerjanya.

Berbagai peneliti telah menguji hubungan dan pengaruh partisipasi anggaran dan kinerja manajerial, namun hasil penelitiannya menunjukkan perbedaan. (Cherrington dan Cherrington 1973; Kenis, 1973; Milani, 1975) menemukan bahwa 
partisipasi anggaran mempunyai pengaruh yang tidak signifikan terhadap kinerja manajerial. Nouri dan Parker (1998) menyatakan bahwa partisipasi anggaran akan menimbulkan adanya kecukupan anggaran dan kemudian mempengaruhi kinerja manajerial serta variabel komitmen organisasi memoderasi hubungan antara partisipasi penganggaran terhadap kinerja manajerial

Hapsari (2010) membuktikan bahwa partisipasi dalam penyusunan anggaran berpengaruh positif dan signifikan terhadap kinerja manajerial. Hasil interaksi komitmen organisasi dan locus of control juga positif dan signifikan mempengaruhi hubungan antara partisipasi penyusunan anggaran dan kinerja manajerial. Udani (2010) menunjukkan bahwa partisipasi penyusunan anggaran berpengaruh positif terhadap kinerja manajerial. Hasil dari variabel komitmen organisasi memoderasi hubungan antara partisipasi penyusunan anggaran terhadap kinerja manajerial.

Hubungan antar variabel yang akan dibahas dalam penelitian ini yang pertama adalah hubungan antara variabel partisipasi penyusunan anggaran dalam mempengaruhi kinerja aparat pemerintah daerah, yang kedua akan membahas hubungan variabel budaya organisasi dalam memoderasi hubungan partisipasi penyusunan anggaran pada kinerja aparat pemerintah daerah, yang ketiga akan membahas hubungan variabel motivasi dalam memoderasi hubungan partisipasi penyusunan anggaran pada kinerja aparat pemerintah daerah, yang keempat akan membahas hubungan variabel gaya kepemimpinan dalam memoderasi hubungan partisipasi anggaran pada kinerja aparat pemerintah daerah. 
Kinerja aparat pemerintah merupakan salah satu faktor yang dapat meningkatkan efektivitas organisasi. Partisipasi bawahan dalam penyusunan anggaran dan peran anggaran sebagai pengukur kinerja memiliki kaitan yang cukup kuat. Anggaran yang telah ditetapkan berfungsi sebagai perencanaan dan sebagai kriteria kinerja, yaitu anggaran dipakai sebagai suatu sistem pengendalian untuk mengukur kinerja aparat pemerintah. Sikap dan perilaku anggota organisasi dalam penyusunan anggaran perlu melibatkan manajemen pada level yang lebih rendah sehingga anggaran partisipatif dapat dinilai sebagai pendekatan manajerial yang dapat meningkatkan kinerja setiap anggota organisasi sebagai individual karena dengan adanya partisipasi dalam penyusunan anggaran diharapkan setiap individu mampu meningkatkan kinerjanya sesuai dengan target yang telah ditentukan Bambang Sardjito dan Osmad Muthaher (2007) sesuai dengan pengertian dari teori penetapan tujuan atau goal setting theory. Hipotesis yang diajukan dalam penelitian ini adalah sebagai berikut:

H1: Partisipasi penyusunan anggaran berpengaruh positif pada kinerja Aparat Pemerintah Daerah. Budaya organisasi merupakan nilai-nilai dari keyakinan yang dimiliki para anggota organisasi yang dituangkan dalam bentuk norma-norma perilaku para individu atau kelompok organisasi ditempat individu tersebut bekerja (Hofstede et.al 1990). Penelitian yang dilakukan oleh Soewito dan Sugiyanto (2001) menunjukkan bahwa budaya berpengaruh signifikan terhadap tercapainya kinerja karyawan yang tinggi. Hasil penelitian yang dilakukan oleh Masrukhin dan Waridin (2006) dan 
Yuwalliatin (2006) menunjukkan adanya pengaruh positif dari budaya organisasi terhadap kinerja karyawan. Berdasarkan hasil penelitian yang berkaitan dengan budaya, ditentukan bahwa dimensi budaya mempunyai pengaruh terhadap penyusunan anggaran dalam meningkatkan kinerja manajerial, sehingga dapat dirumuskan hipotesis sebagai berikut:

$\mathrm{H} 2$ : Budaya organisasi memoderasi pengaruh positif partisipasi penyusunan anggaran pada kinerja Aparat Pemerintah Daerah.

Partisipasi penyusunan anggaran sebagai suatu mekanisme dalam pertukaran informasi memungkinkan karyawan untuk memperoleh pemahaman yang lebih jelas tentang pekerjaan mereka. Partisipasi tersebut juga membantu mereka untuk memperbaiki kesalahannya, yang pada akhirnya dapat meningkat kinerjanya (Hopwood, 1976). Sebaliknya karyawan yang memiliki motivasi kurang baik (rendah), keinginan untuk memperbaiki kesalahannya relatif rendah, jika kinerja yang mereka peroleh tidak sesuai dengan yang diharapkan (rendah). Dengan kata lain karyawan yang memiliki motivasi kerja rendah tidak memiliki keinginan dengan memanfaatkan partisipasi dalam penyusunan anggaran yang ada, sehingga kinerja yang diperoleh tetap rendah.

Dapat disimpulkan bahwa partisipasi penyusunan anggaran, mungkin lebih efektif apabila karyawan/manajer memiliki motivasi yang lebih baik (tinggi), yang pada akhirnya kinerja yang diperoleh akan semakin tinggi pula. Dengan menggunakan goal setting theory, mengijinkan individu untuk melihat hasil kerja disaat ini dan membandingkannya dengan hasil dimasa lalu. Hal ini akan 
menimbulkan sebuah motivasi tersendiri bagi individu untuk lebih berusaha lebih baik lagi. Berdasarkan hasil penelitian yang berkaitan dengan motivasi, ditentukan bahwa motivasi mempunyai pengaruh terhadap penyusunan anggaran dalam meningkatkan kinerja aparat pemerintah, sehingga dapat dirumuskan hipotesis sebagai berikut:

H3 : Motivasi memoderasi pengaruh positif partisipasi penyusunan anggaran pada kinerja Aparat Pemerintah Daerah

Gaya kepemimpinan ditinjau dari sisi perilaku individu dalam menjalankan perusahaan merupakan sarana untuk mengantisipasi kondisi persaingan yang semakin tajam (Maharani, 2010). Gaya kepemimpinan dapat dibagi menjadi dua dimensi, yaitu: pertama, struktur inisiatif (initiating structure) yang menunjukkan perilaku pemimpin yang berhubungan dengan kinerja pekerjaan. Kedua, gaya kepemimpinan yang diarahkan kepada keterbukaan dan lebih bersifat humanis (consideration) yang menunjukkan hubungan yang dekat, saling mempercayai dan saling memperhatikan antara pemimpin dan bawahan. Seorang pemimpin dalam menjalankan perusahaan dapat menggunakan gaya apapun yang sesuai pada situasi tertentu (Coster and Ferkatis, 1968). Hasil penelitian tersebut menunjukkan gaya kepemimpinan mempunyai dampak positif terhadap adanya dorongan penyusunan anggaran. Sumarno (2005), mengatakan efektivitas partisipasi penganggaran terhadap kinerja manajerial sangat dipengaruhi oleh gaya kepemimpinan manajemen. Berdasarkan uraian sebelumnya, dapat disusun hipotesis sebagai berikut:

H4: Gaya kepemimpinan memoderasi pengaruh positif partisipasi penyusunan anggaran pada kinerja Aparat Pemerintah Daerah 


\section{METODE PENELITIAN}

Penelitian ini mengambil lokasi di 31 (tiga puluh satu) SKPD yang ada di Pemerintah Daerah Kabupaten Lombok Utara yang merupakan instansi yang memberikan pelayanan kepada masyarakat. Penyebaran kuesioner dilakukan satu bulan yaitu bulan Juli 2016 sampai dengan Agustus 2016.

Populasi bukan hanya sekedar jumlah yang ada pada obyek atau subyek yang dipelajari, tetapi meliputi seluruh karakteristik atau sifat yang dimiliki oleh subyek atau obyek itu (Sugiyono, 2010). Populasi dalam penelitian ini adalah Satuan Kerja Perangkat Daerah (SKPD) di Pemerintah Daerah Kabupaten Lombok Utara sejumlah 31 dinas. Pemerintah Daerah Kabupaten Lombok Utara menjadi tempat penelitian karena merupakan salah satu Pemerintah Daerah yang melaksanakan kewenangan Pemerintah pada Kabupaten/Kota, sesuai dengan Undang-Undang nomor 32 tahun 2004 Tentang Pemerintahan Daerah dan Peraturan Pemerintah Republik Indonesia Nomor 38 Tahun 2007.

Teknik pengambilan sampel yang digunakan adalah purposive sample. Kriteria sampel yang digunakan dalam penelitian ini adalah (1) Pegawai yang bekerja di lingkungan Pemerintah Daerah Kabupaten Lombok Utara. (2) Pegawai yang menjabat sebagai Sekretaris/setingkat Sekretaris SKPD, Kepala Bidang/setingkat Kepala Bidang, dan Kepala Seksi/setingkat Kepala Seksi yang bertugas di sekretaris daerah, dinas-dinas, kantor, badan, dan lembaga teknis daerah. Sampel penelitian yang menjadi responden adalah para pejabat yang terlibat langsung dalam proses 
penganggaran yaitu 3 (tiga) orang pejabat di tiap-tiap SKPD. Jumlah responden penelitian sebanyak 93 orang (3 orang x 31 SKPD). Alasan pemilihan sampel tersebut adalah pegawai yang menjabat posisi tersebut ikut serta dalam penyusunan anggaran sehingga dapat memberikan informasi kepada peneliti, tentang sejauh mana SKPD ikut serta dalam partisipasi anggaran Pemerintah Daerah Kabupaten Lombok Utara secara keseluruhan dengan melakukan pengujian terhadap tiga faktor yaitu: budaya organisasi, motivasi dan gaya kepemimpinan dalam partisipasi penyusunan anggaran pada kinerja aparat pemerintah.

Teknik analisis data yang digunakan dalam penelitian ini adalah analisis regresi sederhana dan regresi moderasi interaksi untuk menguji semua hipotesis. Dengan bantuan komputer program Statistical Package and Social Science (SPSS) 22.0 for windows memberikan nilai Alpha Cronbach > 0.60 (Ghozali, 2009). Uji asumsi klasik adalah persyaratan statistik yang harus dipenuhi pada analisis regresi yang berbasis Ordinary Least Square (OLS). Pengujian asumsi klasik bertujuan untuk mengetahui dan menguji kelayakan atas model regresi yang digunakan dalam penelitian supaya hasilnya BLUE atau Best Linear Unbiased Estimator (Ghozali, 2006). Uji asumsi klasik yang akan dilakukan pada penelitian ini hanya uji normalitas dan heteroskedastisitas. Uji multikolinearitas tidak dilakukan pada model regresi yang menggunakan Moderated Regression Analysis (MRA) karena cenderung menimbulkan masalah multikolinearitas. Demikian juga dengan uji autokorelasi tidak dilakukan pada model regresi karena data pada penelitian ini berupa data cross 
section dan kuesioner bukan time series. Pada penelitian ini pengujian asumsi klasik dilakukan untuk memastikan bahwa di dalam model regresi yang digunakan tidak terdapat heteroskedastisitas dan nilai residual data yang dihasilkan berdistribusi normal.

Teknis analisis regresi linier sederhana digunakan untuk mengetahui ada tidaknya pengaruh variabel bebas dengan variabel terikat. Model regresi untuk menguji hipotesis 1 ditunjukkan dalam persamaan sebagai berikut:

$\mathrm{Y}=\alpha+\beta_{1} \mathrm{X}_{1}+\varepsilon$

Keterangan:

$\mathrm{Y}=$ kinerja aparat pemerintah

$\alpha=$ konstanta

$ß 1=$ koefisien regresi variabel $\mathrm{X} 1$

$\mathrm{X} 1=$ partisipasi penyusunan anggaran

$\varepsilon=$ variabel pengganggu

Analisis regresi digunakan untuk melihat ketergantungan variabel dependen dengan satu atau lebih variabel dependen, dengan tujuan untuk mengestimasi nilai rata-rata variabel dependen berdasarkan nilai variabel independen yang diketahui (Gujarati, 2003 dalam Ghozali, 2006).

Model persamaan regresi yang digunakan dalam penelitian ini diasumsikan linear dan diuji dengan tingkat signifikansi 5\%. Hipotesis diuji dengan menggunakan teknik analisis regresi linear berganda dengan menggunakan Moderated Regression Analysis (MRA). Uji interaksi atau sering disebut MRA merupakan aplikasi khusus regresi linear berganda dimana dalam persamaan regresinya mengandung unsur 
interaksi (perkalian dua atau lebih variabel independen). Model persamaan regresi yang akan diuji adalah sebagai berikut:

$$
\begin{aligned}
& \mathrm{Y}=\alpha 0+\beta 1 \mathrm{PP}+\beta 2 \mathrm{BO}+\beta 3 \mathrm{MO}+\beta 4 \mathrm{GK}+\beta 5 \mathrm{PP} * \mathrm{BO}+\beta 6 \mathrm{PP} * \mathrm{MO}+ \\
& \beta 7 \mathrm{PP} * \mathrm{GK}+\mathrm{e}
\end{aligned}
$$

Keterangan:

$\mathrm{Y}=$ Kinerja Aparat Pemerintah

$\alpha 0=$ konstanta

$\beta 1-7=$ koefisien regresi

$\mathrm{PP}=$ partisipasi penyusunan anggaran

$\mathrm{BO}=$ budaya organisasi

$\mathrm{MO}=$ motivasi

$\mathrm{GK}$ = gaya kepemimpinan

$\mathrm{PP} * \mathrm{BO}=$ interaksi antara partisipasi penganggaran dengan budaya organisasi

$\mathrm{PP}^{*} \mathrm{MO}=$ interaksi antara partisipasi penganggaran dengan motivasi.

$\mathrm{PP} * \mathrm{GK}=$ interaksi antara partisipasi penganggaran dengan gaya kepemimpinan.

$\mathrm{e}=$ error

Dengan menggunakan uji interaksi, hasil olahan data dapat diinterpretasikan

sebagai berikut:

\section{1) Uji Ketepatan Model}

Uji Anova atau $\mathrm{F}$ test menghasilkan nilai $\mathrm{F}$ hitung dengan tingkat signifikansi tertentu, jika tingkat signifikansinya jauh lebih kecil dari 0,05 maka model regresi dapat digunakan untuk memprediksi senjangan anggaran.

2) Uji Hipotesis

Uji hipotesis dilakukan dengan melihat hasil uji t pada masing-masing persamaan regresi. Dengan bantuan SPSS maka nilai thitung dapat diketahui, jika nilai 
signifikansi t hitung $\leq$ 0,05 untuk semua variabel berarti H0 ditolak dan semua hipotesis alternatif diterima.

\section{HASIL DAN PEMBAHASAN}

Berdasarkan Sembilan puluh tiga kuesioner yang disebar, kuesioner yang digunakan adalah sebanyak semiblan puluh tiga kuesioner (seratus persen). Hasil pengujian validitas menunjukkan semua butir pertanyaan kuesioner mempunyai nilai koefisien korelasi lebih besar dari 0,3, yang artinya valid. Hasil pengujian reliabilitas menunjukkan semua instrumen mempunyai nilai cronbach's alpha lebih besar dari 0,6, yang artinya reliabel.

Untuk melihat apakah data yang digunakan dalam penelitian telah terdistribusi normal dapat dilihat dengan menggunakan uji non parametrik satu sampel Kolmogorov-Smirnov. Hasil uji Kolmogorov-Smirnov model 1 dan model 2 bahwa unstadarized residu memiliki nilai Asymp.Sig (2-tailed) diatas 0,05. Hal ini berarti data telah terdistribusi normal. Uji heteroskedastisitas dalam penelitian ini dilakukan dengan uji glejser. Model regresi tidak mengandung adanya heteroskedastisitas bila nilai signifikansi variabel bebasnya terhadap nilai absolut residual statistik diatas $\alpha=0,05$. Hasil uji heteroskedastisitas tersebut memiliki nilai signifikansi masing-masing variabel di atas $\alpha=0,05$. Jadi, dapat disimpulkan bahwa model regresi tidak mengandung adanya heteroskedastisitas.

Hasil pengujian hipotesis pertama dapat dilihat pada Tabel 1 yaitu sebagai berikut. 
Tabel 1

\section{Hasil Uji Regression Sederhana}

Coefficients $^{\mathrm{a}}$

\begin{tabular}{|c|c|c|c|c|c|c|}
\hline \multirow[b]{2}{*}{ Model } & & \multicolumn{2}{|c|}{ Unstandardized Coefficients } & \multicolumn{3}{|c|}{$\begin{array}{l}\text { Standardized } \\
\text { Coefficients }\end{array}$} \\
\hline & & B & Std. Error & Beta & $\mathrm{T}$ & Sig. \\
\hline \multirow[t]{2}{*}{1} & (Constant) & -24.370 & 2.639 & & -9.233 & 0.000 \\
\hline & $\mathrm{X}$ & 3.156 & .155 & .906 & 20.415 & 0.000 \\
\hline
\end{tabular}

a. Dependent Variable: $\mathrm{Y}$

Sumber: Lampiran 5, 2016

Berdasarkan Tabel 5.6 dapat dibuat suatu model persamaan regresi yaitu sebagai berikut.

$Y=-24,370+3,156 X 1$

Tabel 5.6, menunjukkan bahwa variabel partisipasi penyusunan anggaran berpengaruh positif dengan nilai unstandardized coefficients sebesar 3,156 dan nilai tingkat signifikansi sebesar 0,000 sehingga dapat disimpulkan bahwa partisipasi penyusunan anggaran berpengaruh postif pada kinerja aparat pemerintah daerah.

Hasil pengujian hipotesis kedua, ketiga dan keempat dapat dilihat pada Tabel 2 yaitu sebagai berikut.

Tabel 2

Hasil Uji Moderated Regression Analysis

Coefficients $^{\mathrm{a}}$

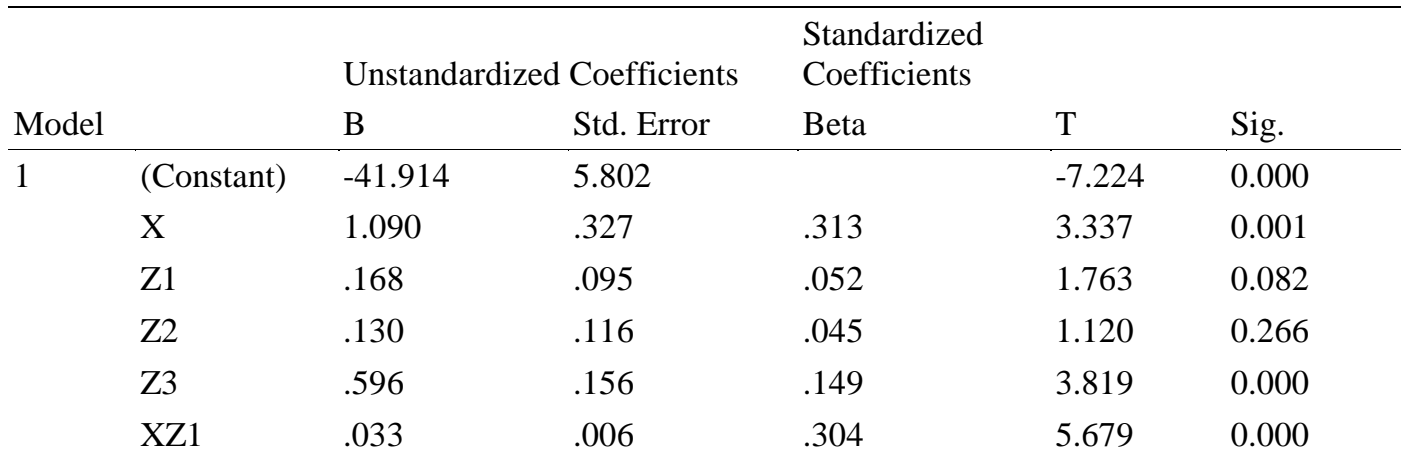




\begin{tabular}{llllll} 
XZ2 & .028 & .007 & .322 & 4.078 & 0.000 \\
$\mathrm{XZ3}$ & .019 & .009 & .113 & 2.111 & 0.038 \\
\hline
\end{tabular}

a. Dependent Variable: $\mathrm{Y}$

Sumber: Lampiran 6, 2016

Berdasarkan Tabel 2 dapat dibuat suatu model persamaan regresi yaitu sebagai berikut.

$Y=-41,914+1,090 X 1+0,168 Z 1+0,130 Z 2+0,596 Z 3+0,033 X . Z 1+0,028 X . Z 2$ $+0,019$ X.Z3

Berdasarkan model persamaan regresi tersebut dapat diungkapkan informasi sebagai berikut:

1) Nilai konstanta $=-41,914$ artinya, apabila variabel partisipasi penyusunan anggaran, budaya organisasi, motivasi, gaya kepemimpinan dan interaksi partisipasi penyusunan anggaran, budaya organisasi, motivasi, gaya kepemimpinan dengan kinerja aparat pemerintah daerah dianggap konstan maka kinerja aparat pemerintah cenderung menurun sebesar $(-41,914)$..

2) Nilai koefisien regresi gaya kepemimpinan $=0,596$ artinya apabila variabel gaya kepemimpinan cenderung meningkat sebesar 1 satuan maka variabel kinerja aparat pemerintah meningkat sebesar $(0,596)$ dengan asumsi variabel lainnya konstan.

3) Nilai koefisien regresi interaksi $\left|\mathrm{X}-\mathrm{ZX}_{1}\right|=0,033$ artinya apabila interaksi variabel partisipasi penyusunan anggaran dan budaya organisasi $\left(\mathrm{X} . \mathrm{Z}_{1}\right)$ cenderung meningkat sebesar 1 satuan maka variabel kinerja aparat pemerintah akan meningkat sebesar $(0,033)$ dengan asumsi variabel lainnya konstan. 
4) Nilai koefisien regresi interaksi $\left|\mathrm{X}-\mathrm{ZX}_{2}\right|=0,331$ artinya apabila interaksi partisipasi penyusunan anggaran dan motivasi $\left(X . Z_{2}\right)$ cenderung meningkat sebesar 1 satuan maka variabel kinerja aparat pemerintah akan meningkat sebesar $(0,331)$ dengan asumsi variabel lainnya konstan.

5) Nilai koefisien regresi interaksi $\left|\mathrm{X}-\mathrm{ZX}_{3}\right|=0,019$ artinya apabila interaksi variabel partisipasi penyusunan anggaran dan gaya kepemimpinan $\left(\mathrm{X} . \mathrm{Z}_{3}\right)$ cenderung meningkat sebesar 1 satuan maka variabel kinerja aparat pemerintah akan meningkat sebesar $(0,019)$ dengan asumsi variabel lainnya konstan.

Uji koefisien determinasi dilakukan untuk mengetahui seberapa jauh kemampuan variabel bebas (independen) menerangkan variabel terikatnya (dependen), ini dapat dilihat dari nilai $\mathrm{R}^{2}$ yaitu adjusted $\mathrm{R}^{2}$. Berdasarkan Tabel 5.8 nilai $\mathrm{R}^{2}$ sebesar 0,799 , ini berarti sebesar 79,9 persen $(\%)$ variabel partisipasi penyusunan anggaran, budaya organisasi, motivasi, gaya kepempinan dan interaksi variabel partisipasi penyusunan anggaran dengan budaya organisasi, interaksi variabel partisipasi penyusunan anggaran dengan motivasi, interaksi variabel penyusunan anggaran dengan gaya kepemimpinan berpengaruh pada kinerja aparat pemerintah, sedangkan sisanya sebesar 20,1 persen dipengaruhi oleh variabel lain yang tidak dimasukan dalam penelitian.

Uji kelayakan model (uji F) bertujuan untuk menguji apakah semua variabel bebas berpengaruh pada variabel terikat dan untuk mengetahui model regresi yang digunakan dalam penelitian ini layak uji atau tidak. Berdasarkan Tabel 5.9 diperoleh 
nilai dari signifikansi 0,000 yang lebih kecil dari 0,05. Ini berarti bahwa ada pengaruh antara variabel partisipasi penyusunan anggaran, interaksi variabel partisipasi penyusunan anggaran dengan budaya organisasi, interaksi variabel partisipasi penyusunan anggaran dengan motivasi, interaksi variabel partisipasi penyusunan anggaran dengan gaya kepemimpinan, pada kinerja aparat pemerintah.

Berdasarkan hasil penelitian diperoleh variabel partisipasi penyusunan anggaran berpengaruh signifikan pada kinerja aparat pemerintah. Variabel partisipasi penyusunan anggaran memberikan nilai parameter 3,156 dengan tingkat signifikasi 0,000. Sehingga hipotesis pertama diterima yaitu partisipasi penyusunan anggaran berpengaruh positif pada kinerja aparat pemerintah daerah. Kinerja aparat pemerintah merupakan salah satu faktor yang dapat meningkatkan efektivitas organisasi. Partisipasi bawahan dalam penyusunan anggaran dan peran anggaran sebagai pengukur kinerja memiliki kaitan yang cukup kuat. Anggaran yang telah ditetapkan berfungsi sebagai perencanaan dan sebagai kriteria kinerja, yaitu anggaran dipakai sebagai suatu sistem pengendalian untuk mengukur kinerja aparat pemerintah.

Berdasarkan hasil penelitian diperoleh variabel moderasi yang merupakan interaksi antara partisipasi penyusunan anggaran dan budaya organisasi ternyata signifikan $($ sig=0,00) sehingga dapat disimpulkan bahwa variabel budaya organisasi merupakan variabel moderating. Budaya organisasi merupakan nilai-nilai dari keyakinan yang dimiliki para anggota organisasi yang dituangkan dalam bentuk 
norma-norma perilaku para individu atau kelompok organisasi ditempat individu tersebut bekerja (Hofstede et.al 1990).

Berdasarkan hasil penelitian diperoleh variabel moderasi yang merupakan interaksi antara partisipasi penyusunan anggaran dan motivasi ternyata signifikan $($ sig=0,00) sehingga dapat disimpulkan bahwa variabel motivasi merupakan variabel moderating. Partisipasi penyusunan anggaran sebagai suatu mekanisme dalam pertukaran informasi memungkinkan karyawan untuk memperoleh pemahaman yang lebih jelas tentang pekerjaan mereka. Partisipasi tersebut juga membantu mereka untuk memperbaiki kesalahannya, yang pada akhirnya dapat meningkat kinerjanya (Hopwood, 1976).

Berdasarkan hasil penelitian diperoleh variabel moderasi yang merupakan interaksi antara partisipasi penyusunan anggaran dan gaya kepemimpinan ternyata signifikan $(\operatorname{sig}=0,00)$ sehingga dapat disimpulkan bahwa variabel gaya kepemimpinan merupakan variabel moderating.

\section{SIMPULAN DAN SARAN}

Berdasarkan hasil analisis dan uraian pada bab-bab sebelumnya, maka dapat diperoleh simpulan adalah sebagai berikut. Partisipasi penyusunan anggaran berpengaruh positif pada kinerja aparat pemerintah. Sehingga, hipotesis pertama dalam penelitian ini diterima. Budaya organisasi memperkuat pengaruh partisipasi penyusunan anggaran pada kinerja aparat pemerintah. Sehingga, hipotesis kedua dalam penelitian ini diterima. Motivasi memperkuat pengaruh partisipasi penyusunan 
anggaran pada kinerja aparat pemerintah. Sehingga, hipotesis ketiga dalam penelitian ini diterima. Gaya kepemimpinan memperkuat pengaruh partisipasi penyusunan anggaran pada kinerja aparat pemerintah. Sehingga, hipotesis keempat dalam penelitian ini diterima.

Berdasarkan hasil penelitian dan simpulan yang diperoleh penelitian yang ada, maka dapat dikemukakan saran-saran sebagai berikut. Dalam partisipasi penyusunan suatu anggaran hendaknya pegawai yang ikut dalam berpartisipasi menyusun anggaran lebih memahami tugasnya dalam menentukan sasaran anggaran dibagiannya masing-masing. Hal ini seiring dengan upaya peningkatan kinerja aparat pemerintah daerah Kabupaten Lombok Utara. Diharapkan agar aparat pemerintah daerah lebih memperhatikan budaya organisasi dengan lebih mengutamakan pada hasil kerja dan lebih meningkatkan kerjasama dalam partisipasi penyusunan anggaran. Hal ini sebaiknya tidak hanya sekedar syarat, namun harus direalisasikan agar seiring dengan peningkatan kinerja aparat pemerintah daerah Kabupaten Lombok Utara. Peneliti selanjutnya dapat mengembangkan penelitian ini dengan mempertimbangkan variabel intern atau variabel external dari partisipasi penyusunan anggaran lain yang mungkin berpengaruh pada kinerja aparat pemerintah daerah yang tidak diteliti, agar dapat diketahui faktor-faktor yang paling berpengaruh pada kinerja aparat pemerintah daerah dalam rangka pengembangan dan pemberdayaan serta peningkatan kinerja aparat pemerintah daerah itu sendiri. 


\section{REFERENSI}

Andrianto, Yogi. 2008. "Analisis Pengaruh Partisipasi Penyusunan Anggaran Terhadap Kinerja Manajerial Dengan Kepuasan Kerja, Job relevant Information dan Kepuasan Kerja Sebagai Variabel Moderating (Studi Empiris Pada Rumah Sakit Swasta di Wilayah Kota Semarang)" (Tesis). Semarang: Universitas Diponegoro.

Anthony, R.N., Dearden, J and Bedford. 1998. Management Control System. New York: Irwin Mc Graw-Hill.

Astuti, E.D. 2007. "Pengaruh Ketidakpastian Lingkungan Terhadap Karakteristik Informasi Sistem Akuntansi Manajemen Dengan Moderasi Locus of Control Pada Perusahaan Manufaktur di Daerah Istimewa Yogyakarta dan Jawa Tengah” (Skripsi). Yogyakarta: Universitas Islam Indonesia.

Bangun, A. 2009. "Pengaruh Partisipasi dalam Penyusunan Anggaran, Kejelasan Sasaran Anggaran dan Struktur Desentralisasi Terhadap Kinerja Manajerial Skpd dengan Pengawasan Internal sebagai Variabel Pemoderasi (Studi Kasus pada Pemerintahan Kabupaten Deli Serdang)". Tesis, Sekolah Pascasarjana Universitas Sumatera Utara, Medan.

Becker, S. and D. Green 1962. "Budgeting and Employee Behavior". Journal of Business. October. pp. 392-402.

Brownell, P. 1981. Participation ib Budgetting Process, Locus of Control and Organizational Effectiveness. The Accounting Review, Vol. LVI, No.4, pp. 844860 .

Brownell, P. 1982a. Participation in budgeting Proces : When It Works and It Doesn't. Journal of Accounting Literature, Vol. 1, pp. 124-153.

Brownell, P. 1982b. A Field Study Examination of Budgetary Participation and Locus of Control. The Accounting Review, Vol. L. VII, No. 4, pp. 766-777.

Chong, V.K. dan Kar Min Chong. 2002. Budget Goal Commitment and Informational Effects of Budget Participation on Performance: A Structural Equation Modelling Approach. Behavioral Research in Accounting, Vol. 1, pp. 65-86.

Coster, T. D. and Fertakis, P. J. 1968. Budget-induced pressure and its relationship to supervisory behavior. Journal of accounting research (Autumn). pp. 237-246. 
Fruchot, Veronique dan Shearon Winston T. 1991. Budgetary Participation, Locus of Control, and Mexican Managerial. Performance and Job Satisfaction. The Accounting Review, Vol. 66, No. 1. Pp. 80-99.

Gary, Y. 1998. Kepemimpinan Dalam Organisasi. Terjemahan: Yusuf Udaaya. Prenhallindo. Jakarta.

Gibson, J.L. Ivancevic, J.M., Donnely, Jr. J.H. 2001. Organizational Behavior, Structur and Process. Burr Ridge, Irwin McGraw-Hill.

Govindarajan, V. 1986. Impact of Participation in The Budgetary Process on Managerial Attitudes and Performance: Universalistic and Contigency Perspective. Decision Sciences 17. pp. 496-516.

Gul, F.A., Tsui, J.S., Fong, S.C.C. and Kwok, H.Y.L. 1995. Decentralization as a Moderating Factor in the Budgetary Participation-Performance Relationship: Some Hong Kong Evidences.

Halim, Abdul dan Theresia Damayanti. 2007. Pengelolaan Keuangan Daerah: Seri Bunga Rampai Manajemen Keuangan Daerah. Yogyakarta: UPP STIM YKPN.

Helkamp. 1990. Managerial Acounting. Second Edition. John Wiley \& Son Inc.

Hapsari, N. A. R. 2010. Pengaruh Partisipasi Penyusunan Anggaran Terhadap Kinerja Manajerial Dengan Komitmen Organisasi dan Locus of Control Sebagai Variabel Moderasi (Studi Kasus Pada PT Adhi Karya (Persero) Tb. Divisi Konstruksi I), Skripsi. Fakultas Ekonomi Universitas Diponegoro. Semarang.

Mahoney, T.A, T.H. Jerdee dan S.J. Carroli. 1963. Depelopment of Managerial Attitude Performance. A Research Approach, Cincinnati. Ohio: Soutt Western Publishing Co.

Mardiasmo. 2009. Akuntansi Sektor Publik. Edisi IV. Yogyakarta: Andi Offset.

Merchant, K. A. 1981. "the Design of The Corporate Budgeting System: Influences on Managerial Behavior and Performance". The Accounting Review. pp. 813828.

Milani, K. 1975. The Relationship of Participation in Budget-Setting on Industrial Supervisor Performance and Attitudes: A Field Study. The Accounting Review 50. April. pp. 104-123. 
Mitchell, T. R. 1982. "Motivation: New Direction for Theory, and Pratices". Academy of Management Review. Vol. 7. No.1. pp. 80-88.

Mowday, R.R. Steers dan L. Porter, 1979. The Measurement of Organizational Commitment. Journal of Vocational Behaviour 14, pp: 224-235.

Munandar, M. 2001. Budgeting: Perencanaan Kerja Pengkordinasian Kerja Pengawasan Kerja, Yogyakarta: BPFE-YOGYAKARTA

Murray. D. 1988. The Performance Effects of Participative Budgeting: An Integration of Intervening and Moderating Variables. Behavior Researchan Accounting. Vol.2

Murray, D. 1990. "The Performance Effect of Participative Budgeting: An Integration of Intervening and Moderating Variables". Behavioral Research in Accounting. Vol. 2. pp. 104-123.

Muthaher, B. S. O. 2007. Pengaruh Partisipasi Penyusunan Anggaran Terhadap Kinerja Manajerial Aparat Pemerintah Daerah: Budaya Organisasi dan Komitmen Organisasi sebagai Variabel Moderating. Simposium Nasional Akuntansi (SNA) X. 26-28 Juli. Makasar.

Nafirin, M. 2007. Penganggaran Perusahaan. Jakarta: Salemba Empat.

Ngatemin. 2009. "Pengaruh Komitmen Organisasi dan Locus of Control Terhadap Hubungan Antara Partisipasi Penyusunan Anggaran dan Kinerja Manajerial Pada Badan Pengembangan Sumber Daya Kebudayaan dan Pariwisata Departemen Kebudayaan dan Pariwisata Republik Indonesia" (Tesis). Medan: Univeristas Sumatera Utara (USU).

Nor, Wahyudin. 2007. Desentralisasi dan Gaya Kepemimpinan Sebagai Variabel Moderating Dalam Hubungan Antara Partisipasi Penyusunan Anggaran dan Kinerja Manajerial. Simposium Nasional Akuntansi X, Makasar, hal.1-27.

Nursidin, M. 2008. "Pengaruh Anggaran Partisipatif Terhadap Kinerja Manajerial Melalui Kesenjangan Anggaran dan Motivasi Kerja Pada PT. (PERSERO) Pelabuhan Indonesia - I Medan" (Tesis). Medan: Universitas Sumatera Utara (USU).

Oktiana, P. M. T. 2011. Pengaruh Komitmen Organisasi dan Budaya Organisasi Pada Hubungan Antara Partisipasi Penyusunan Anggaran Dengan Kinerja Manajerial Pada Dinas-Dinas Kabupaten Tabanan. Skripsi Ekonomi. Jurusan Akuntansi. FE UNUD. Denpasar. 
Rini, W. S. 2001. Pengaruh Struktur Organisasional dan Ketidakpastian Lingkungan Terhadap Efektivitas Sistem Informasi Ditinjau dari Dimensi Kualitas Pelayanan. Tesis. S2, Universitas Gadjah Mada: Yogyakarta.

Ritonga, Panangaran. 2008. "Pengaruh Budaya Paternalistik dan Komitemen Organisasi Terhadap Hubungan Antara Partisipasi Anggaran dan Kinerja Manajerial Pada PDAM Tirtanasi Provinsi Sumatera Utara" (Tesis). Medan: Universitas Sumatera Utara (USU).

Riyadi. 1998. Motivasi dan Pelimpangan Wewenang Sebagai Variabel Moderating dalam Hubungan antara Partisipasi Penyusunan Anggaran dan Kinerja Manajerial. Tesis S2, Universitas Gadjah Mada: Yogyakarta

Riyanto L. S, Bambang. 2001. Alternative Approach to Examining a Contingency Model in Accounting Research: A Comparation. Journal Riset Akuntansi, Manajemen dan Ekonomi, Vol. 1. No. 1, Februari: 1-12.

Riyadingsih, H. 2001. "Hubungan Kemampuan, Orientasi Tujuan, Locus of Control, Motivasi Berprestasi dengan Self Efficacy dan Penetapan Tujuan Dalam Rangka Memprediksi Kinerja Individual” (Tesis). Yogyakarta: Program Magister Sains Universitas Gadjah Mada (dipublikasikan).

Robbins, S. P. dan Timothy A. Judge. 2008. Perilaku Organisasi (Organizational Behavior). Jakarta: Salemba Empat.

Sardjito, Bambang dan Osmad Muthaher. 2007. Pengaruh Partisipasi Penyusunan Anggaran Terhadap Kinerja Aparat Pemerintah Daerah: Budaya Organisasi dan Komitmen Organisasi Sebagai Variabel Moderating. Simposium Nasional Akuntansi X, Makasar, hal.1-24.

Siagian, Sondang P, 2002, "Kiat Meningatkan Produktivitas Kerja", PT. RINEKA CIPTA, Jakarta.

Siegel dan R. Marconi, 1989, Behavioral Accounting, South-Western Publishing,Ohio.

Sugiyono. 2010. Metode Penelitian Bisnis. Edisi ke-15. Bandung: Alfabet. 